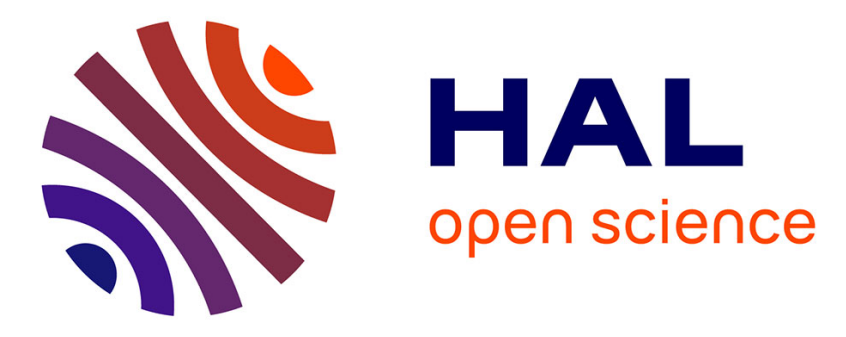

\title{
Radiocarbon Dating of Mortars with a Pozzolana Aggregate Using the Cryo2Sonic Protocol to Isolate the Binder
}

Sara Nonni, Fabio Marzaioli, Silvano Mignardi, Isabella Passariello, Manuela Capano, Filippo Terrasi

\section{To cite this version:}

Sara Nonni, Fabio Marzaioli, Silvano Mignardi, Isabella Passariello, Manuela Capano, et al.. Radiocarbon Dating of Mortars with a Pozzolana Aggregate Using the Cryo2Sonic Protocol to Isolate the Binder. Radiocarbon, 2017, 60 (2), pp.1 - 21. 10.1017/RDC.2017.116 . hal-01683068

\section{HAL Id: hal-01683068 https://hal.science/hal-01683068}

Submitted on 29 Apr 2019

HAL is a multi-disciplinary open access archive for the deposit and dissemination of scientific research documents, whether they are published or not. The documents may come from teaching and research institutions in France or abroad, or from public or private research centers.
L'archive ouverte pluridisciplinaire HAL, est destinée au dépôt et à la diffusion de documents scientifiques de niveau recherche, publiés ou non, émanant des établissements d'enseignement et de recherche français ou étrangers, des laboratoires publics ou privés. 


\title{
RADIOCARBON DATING OF MORTARS WITH A POZZOLANA AGGREGATE USING THE CRYO2SONIC PROTOCOL TO ISOLATE THE BINDER
}

\author{
Sara Nonni ${ }^{1,2 *} \cdot$ Fabio Marzaioli $^{2,3} \cdot$ Silvano Mignardi $^{1} \cdot$ Isabella Passariello $^{2,3} \bullet$ \\ Manuela Capano ${ }^{4}$ Filippo Terrasi ${ }^{2,3}$ \\ ${ }^{1}$ Department of Earth Sciences, Sapienza University of Rome, 00185 Rome, Italy. \\ ${ }^{2}$ CIRCE (Centre for Isotopic Research on Cultural and Environmental Heritage) - INNOVA, 81020 San Nicola \\ La Strada, Caserta, Italy. \\ ${ }^{3}$ Department of Mathematics and Physics, Second University of Naples, 81100 Caserta, Italy. \\ ${ }^{4}$ CIRCE - Second University of Naples; present address: Aix Marseille Univ, CNRS, IRD, Coll France, CEREGE, \\ Aix-en-Provence, France.
}

\begin{abstract}
To date, finding a technique able to effectively isolate the carbon signal from the binder of a mortar is still an open challenge. In this paper, the radiocarbon $\left({ }^{14} \mathrm{C}\right)$ dating of one of the most challenging and diffuse types of mortar, the one with pozzolana aggregate, is investigated. Eight mortar samples from three archaeological sites near Rome (Italy) underwent a selection process called Cryo2SoniC. The selected fractions were analyzed by the accelerator mass spectrometry (AMS) ${ }^{14} \mathrm{C}$ technique and compared to known historical references. Additional scanning electron microscopy analysis and petrographic investigations were done, respectively, to check the grain size of the fractions selected by Cryo2SoniC, and further, to characterize the original mortar samples. The masses of carbon yielded from the dated fractions were almost half of those released from some aerial mortars. The ${ }^{14} \mathrm{C}$ dating results were accurate for pozzolana mortars, from buried and unburied structures, with calcination relics and small contamination of secondary calcite. A limitation in the purification protocol was observed on samples with a massive contamination of secondary calcite deposition of ground water origin, occluding porosity and substituting up to the $80 \%$ of the original binder matrix.
\end{abstract}

KEYWORDS: Cryo2SoniC, mortar, pozzolana, radiocarbon AMS dating, SEM.

\section{INTRODUCTION}

Dating ancient buildings and establishing construction phases is an issue of primary importance for archaeologists when it is not possible or easy to attribute a definite chronology to buildings or the remains of them. Currently, the absolute chronology of archaeological sites relies mostly on stylistic attribution or on the radiocarbon $\left({ }^{14} \mathrm{C}\right)$ dating of organic materials uncovered during the excavations (i.e. charcoals, woods, bones). The absolute dating of a building, applied directly to its own materials, represents a great advantage for the study of an archaeological site and a serious improvement for historical reconstructions.

It is well-known that all building materials based on lime (mortar, concrete, plaster, whitewash) absorb atmospheric carbon dioxide as they harden. Once mortar starts setting, ${ }^{14} \mathrm{C}$ starts decaying, similarly to the organic remains of any plant or animal after its death. Thus, if ${ }^{14} \mathrm{C}$ analysis could be applied to mortar, one would be able to estimate more precisely the time when a certain building was built or modified.

This is far from reality, and even though this principle is simple enough, its application proved to be surprisingly difficult, as shown by the variability in results over more than 50 years of experimentation (Delibrias and Labeyrie 1964; Stuiver and Smith 1965; Baxter and Walton 1970; Folk and Valastro 1976; Pachiaudi et al. 1986; Van Strydonck et al. 1986, 1992; Mathews 2001; Nawrocka et al. 2005, 2009, 2010; Lindroos et al. 2007; Goslar et al. 2009; Heinemeier et al. 2010; Hajdas et al. 2012; Michalska et al. 2013, 2015; Ringbom et al. 2014).

Mortar can be schematically defined as a complex material, mainly composed of a binder and aggregates. The binder represents the most important component of a mortar from the dating

\footnotetext{
*Corresponding author. Email: sara.nonni@uniroma1.it
} 
point of view. It derives from the calcination of primary carbonate rocks and hydration of the calcium oxide forming a workable mass (lime putty) that hardens if exposed to air. Aggregates are applied in order to increase workability, hydration, and to avoid cracks during the setting phase (Cazalla et al. 2000; Lawrence et al. 2003). The typologies of aggregates along with the nature of the binder can completely change the final behavior of a mortar. It is well assessed how the use of materials with a significant concentration of aluminates and amorphous silicates as aggregates (i.e. pozzolana, volcanic ashes and crushed bricks) provides hydraulic properties to lime mortars (Moropoulou et al. 2002, 2005). The designation pozzolana derives from one of the primary deposits of volcanic ash used by the Romans in the neighborhood of Pozzuoli in Italy. Nowadays, the definition of pozzolana includes any pyroclastic material predominantly composed of fine volcanic glass (pumice or volcanic ash) that hardens in water when mixed with calcium hydroxide (lime) or with materials that can release calcium hydroxide (Portland cement clinker; Massazza 1993).

Since Roman times, the use of pozzolana as an additive has been a breakthrough in mortar production technology, allowing hardening under harsh (i.e. humid) climatic conditions and increasing the mechanical resistance. The experience and skills of Roman builders led to what is universally known as pozzolana mortars, where the improved hardening properties are based on chemical reactions involving the slaked lime and the amorphous alumina-silicates of volcanic origin. In the fundamental work of De Architectura, which was considered a handbook for Roman builders, Vitruvius described this material as one capable of hardening both in air and underwater, opening the way to the so-called hydraulic mortars (i.e. mortars able to harden under water, Virtruvius 1931). When volcanic ash was not available, finely ground pottery and ceramics were used to induce hydraulic properties at lower rates to the mortar, producing the so-called cocciopesto, a material well-known since the Minoan society (Moropoulou et al. 2005). A successful dating of pozzolana mortars would have an enormous impact in archaeology and a high potential of applications.

Despite their importance, pozzolana mortars have received less attention than non-pozzolana mortars (i.e. aerial mortars) mostly because of the complications connected with their ${ }^{14} \mathrm{C}$ dating (Hale et al. 2003; Lindroos 2005; Ringbom et al. 2006, 2011, 2014; Hodgins et al. 2011; Lindroos et al. 2011; Michalska and Czernik 2015). In the case of aerial mortars, the method has been experimentally studied and the problems are fairly well understood (Folk and Valastro 1976; Pachiaudi et al. 1986; Ambers 1987; Heinemeier et al. 1997; Lindroos et al. 2007; Marzaioli et al. 2011, 2013, 2014; Al-Bashaireh 2013; Nonni et al. 2013). In dating aerial mortars, the main issue is related to the presence of dead carbon contamination, introduced as incomplete calcined limestone residues (calcination relics) or carbonate fillers (from very fine sand to gravel).

This paper sets out to prove that one of the obstacles in dating pozzolana mortars is the lower content of carbon in pozzolana mortars compared to that of aerial ones. This is due to the interaction of the binder with pozzolana (i.e. characterized by a high hydraulic index; Callebaut et al. 2001; Lindroos et al. 2011) drastically affecting the relative fraction of ${ }^{14} \mathrm{C}$ available to date and enhancing the effect of any contamination eventually present. Other possible causes of failure when dating pozzolana mortars are the following:

- The unpredictability of the moment of hardening. The impermeable nature of pozzolana may retain water into pockets with unreacted $\mathrm{Ca}(\mathrm{OH})_{2}$ that will set a continuous interaction with atmospheric $\mathrm{CO}_{2}$, forming newborn carbonates. Furthermore, their lower permeability to the air (and $\mathrm{CO}_{2}$ ) compared to that of aerial mortars (Ringbom et al. 2011; 
Nonni 2014) may lead to a slower hardening (i.e. thick walls). Both situations increase the risk of rejuvenation, thus resulting in obtaining ages younger than predicted.

- The recurring presence of recrystallization phenomena due to weathering (air-exposed structures) or groundwater (deeply buried structures) activities. These effects could lead to aging as well as rejuvenation, depending on the origin of the recrystallization carbonates (Nonni 2014; Michalska and Czernik 2015) and may affect aerial and pozzolana mortars.

- The presence of carbonate nodules, similar to lime lumps, derived from volcanic activity and found inside volcanic ashes and pozzolana (Miriello et al. 2010). In addition, the presence of limestone fragments derives from bedrock underlying the volcanic districts and forming the walls of conduits where magma travels during explosive eruptions (Jackson and Marra 2006). These types of contamination can lead to aging.

- The presence of natural fine sand from limestone or marble used as additives (i.e. for surface and finishing wall layers) can increase the risk of aging (Nonni 2014). This contamination can lead to aging and can affect any type of mortars.

When a condition of low content of datable carbonate matches the presence of one or more risks of contamination, the chance of success in ${ }^{14} \mathrm{C}$ dating a pozzolana mortar drops down if compared to an aerial one. To be successful, a selection protocol should provide a fraction to date as much representative as possible of the binder and therefore free of any contaminants. Literature reports that chemical reactions produce colloids that flocculate and grow, generating finer particles while geological particles of mechanical origin have grain size bigger than $1 \mu \mathrm{m}$ (Davis and Kent 1990; Salama 2000; Genestar and Pons 2003; Stefanidou and Papayianni 2005; Marzaioli et al. 2011). Therefore, particles $<1 \mu \mathrm{m}$ are more likely to derive from crystal nucleation and/or chemical growth. Several experiments simulating mortar production showed that binder carbonates are characterized by $200-400 \mathrm{~nm}$ fine grain size (Genestar and Pons 2003; Stefanidou and Papayianni 2005; Marzaioli et al. 2011) due to the high hardening rates of lime mortar (Moropoulou et al. 2000; Lanas et al. 2004; El-Turki et al. 2007; KosendarLegenstein et al. 2008). Therefore, fractions to submit to ${ }^{14} \mathrm{C}$ dating should have a homogeneous and sub-micrometric grain dimension. The present study shows how the use of a selection protocol based on cryo-breaking, ultrasonication, and centrifugation, called Cryo2SoniC (Marzaioli et al. 2013; Nonni et al. 2013) led to promising results within a set of samples collected from three different archaeological sites. Previously the Cryo2SoniC and its first version, CryoSoniC, revealed good accuracy for archaeological and synthetic mortars (Marzaioli et al. 2011, 2013, Nonni et al. 2013). In the present study, we aimed to evidence the efficiency and reliability of the Cryo2SoniC protocol on pozzolana mortars from three archaeological structures: the Temple of Minerva Medica and the Tower del Fiscale in the city of Rome, and the remains of a Roman pool in the Archaeological Park of Ostia (Italy). Several aspects of the protocol were investigated. To identify the capability of the Cryo2SoniC protocol to efficiently select a sub-micrometric fraction of powder dimensionally similar to the binder, scanning electron microscopy images were collected. To check the yielding of datable carbon in pozzolana mortars, a comparison was run between fractions collected by Cryo2SoniC. To investigate the efficiency of the Cryo2SoniC selection on pozzolana mortars, ${ }^{14} \mathrm{C}$ dating was performed and the obtained ${ }^{14} \mathrm{C}$ ages were compared to the historical attributions for each site. At the present day, no absolute dating was ever performed for any of the described sites and all reference dates are uniquely from archive sources and relative chronologies. ${ }^{14} \mathrm{C}$ results were discussed integrating the evidences collected from the petrographic analysis of the original mortar samples. 


\section{MATERIALS AND METHODS}

\section{Site Descriptions}

A set of eight samples was collected across three different archaeological sites in Rome (Italy) and its surroundings: the archaeological excavation of Porta Marina in the Archaeological Park of Ostia Antica, the Roman foundations of the medieval tower of Tor del Fiscale in the Aqueducts Park, and the Temple of Minerva Medica in Rome's city center (Figure 1).

The Roman site of Porta Marina is an ongoing excavation led by the Department of History, Cultures and Civilizations of the University of Bologna as part of the Ostia Marina Project (David et al. 2009, 2014; David and Gonzales 2011; David and Turci 2011; Morricone et al. 2013; Valeri 2001). Porta Marina is a neighborhood area on the border of the Archaeological Park of the Ostia Antica, once the harbor of ancient Rome. The excavations include a thermal bath complex of $2000 \mathrm{~m}^{2}$, called the Bath of Silenum. The bath complex dates back to Hadrian's age, as attested by the finding of numerous stamped bricks (David et al. 2011, 2014), connected to consuls Apronianus and Paetinus (123 AD) and Verus and Ambibulus (126 AD). The active life of the baths was characterized by different stages of development up to the 5th century. In particular, the structures involved in our study (ambient 7; David et al. 2014) belong to a monumental pool called natatio (an open-air bathing pool; Figure 2), chronologically attributed to the first development of the baths.

The second site is a tower called Tor Del Fiscale, located in the Aqueduct Park along the ancient Via Latina (Figure 1). The well-preserved medieval tower (12th-13th century; Figure 3) was built on Roman ruins to dominate the intersection of the ancient Roman Claudio (38 AD) and Felice (1585 AD) aqueducts on the remains of the Aqua Marcia aqueduct (144 BC; Staccioli 2002). The medieval attribution of the tower comes from archive sources (Tomassetti 1926; Ward-Perkins 1979; De Rossi 1981; Esposito 1998) while the pre-existing Roman structure has been archaeologically attributed to a restoration done during the Hadrian era. A further

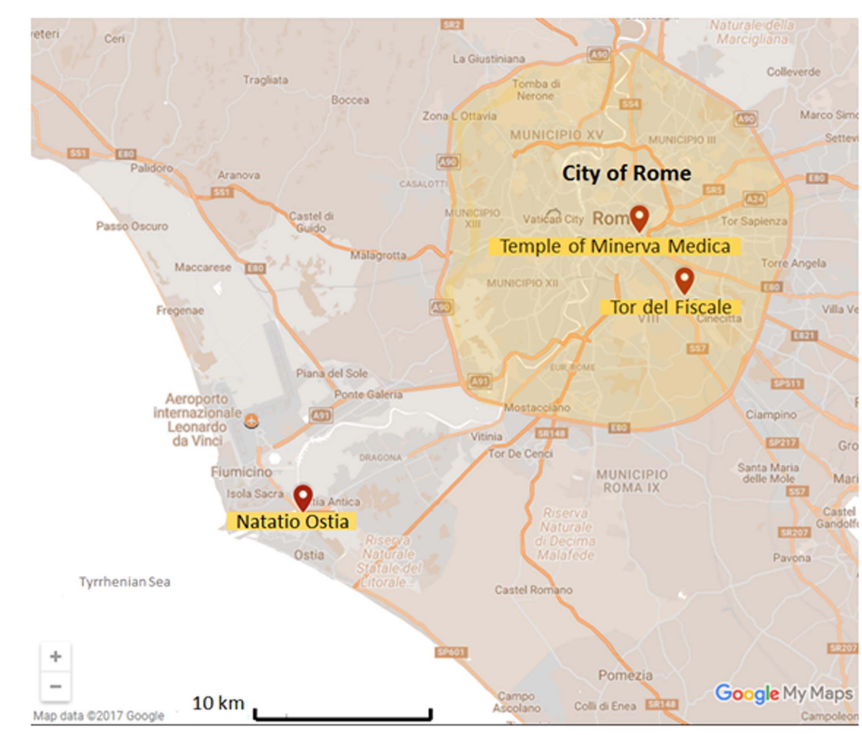

Figure 1 Map of archaeological sites in Rome's city center and nearby Archaeological Park of Ancient Ostia (modified from (C) 2017 Google). 
A

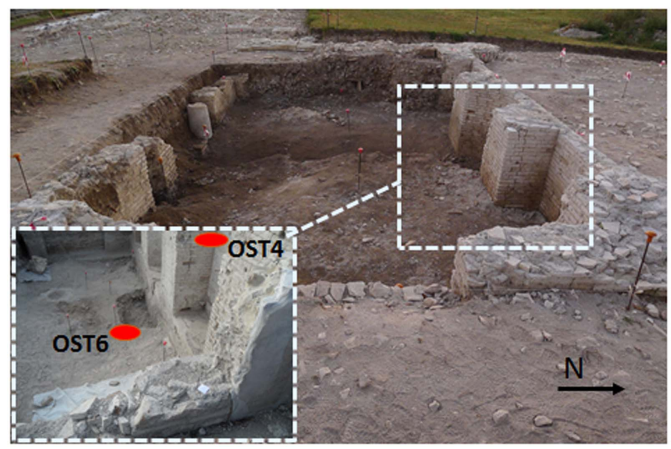

B

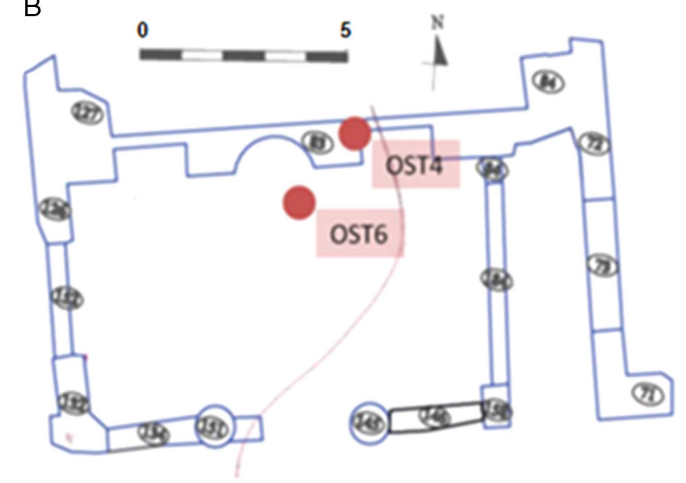

Figure 2 (A) Overview of the natatio at Ostia, during and after the excavations; (B) map showing sampling points on the pillar (OST4) and floor (OST6).

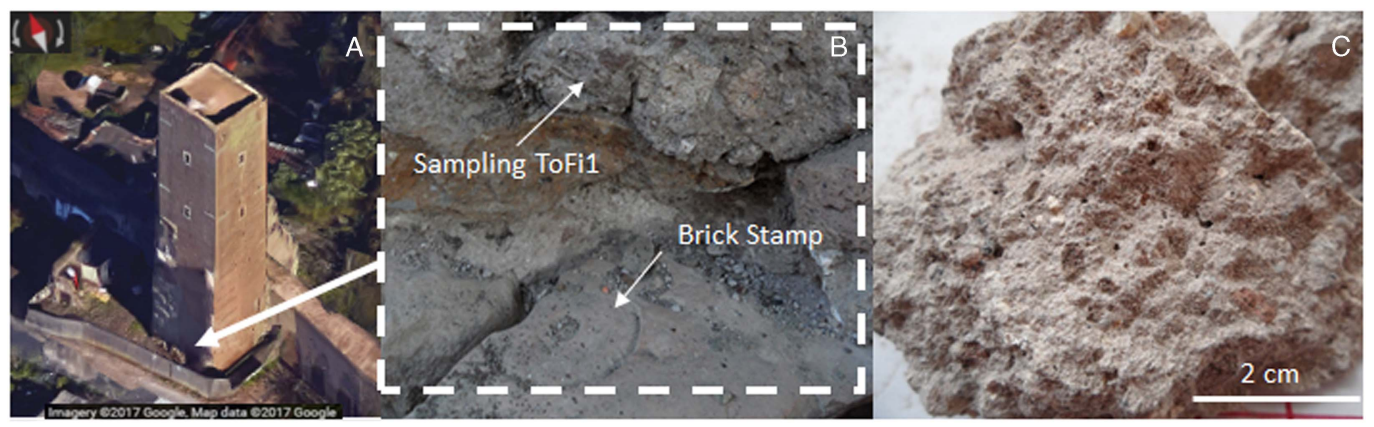

Figure 3 (A) Torre del Fiscale from a satellite image (modified from (C 2017 Google Maps); (B) sampling point at the basement of the tower, close to Hadrian's brick stamp; (C) macroscopic photo of ToFil sample.

confirmation of such attribution is the presence of an imperial brick stamp dated to 123-126 $\mathrm{AD}$ embedded in the wall of the sampling site (Figure 3B).

The third site is the Temple of Minerva Medica, a majestic decagonal building located on Esquilino Hill in Rome's city center (Figures 1 and 4). Its name is related to the discovery, during the 16th century, of a set of statues linked to the cult of medical science, one of which represented the Minerva goddess with a snake. The so-called temple was not always so, as its attributed name suggests, but a monumental hall built during the 4th century, probably under an imperial commission as part of a bigger building complex, now absorbed by the surrounding urban architectures (Biasci 2000). The monumental building, with a massive dome dimensionally comparable to the famous Pantheon, stands on underlying precedent structures attributed to the 1st century (Barbera et at. 2007).

\section{Sampling}

Eight pozzolana mortars used for ${ }^{14} \mathrm{C}$ dating were collected from the joints between bricks and tuffs or within the filling of the Opus Caementitium. All samplings were performed in order to pick up consistent and cohesive pieces of mortar (average dimensions of $6 \mathrm{~cm}^{3}$ ).

Two samples were collected at Porta Marina: OST4 on the top of a column of the northern wall (USM83) and OST6 (US168) on the floor of the natatio pool (Figure 2). Given the lack of 


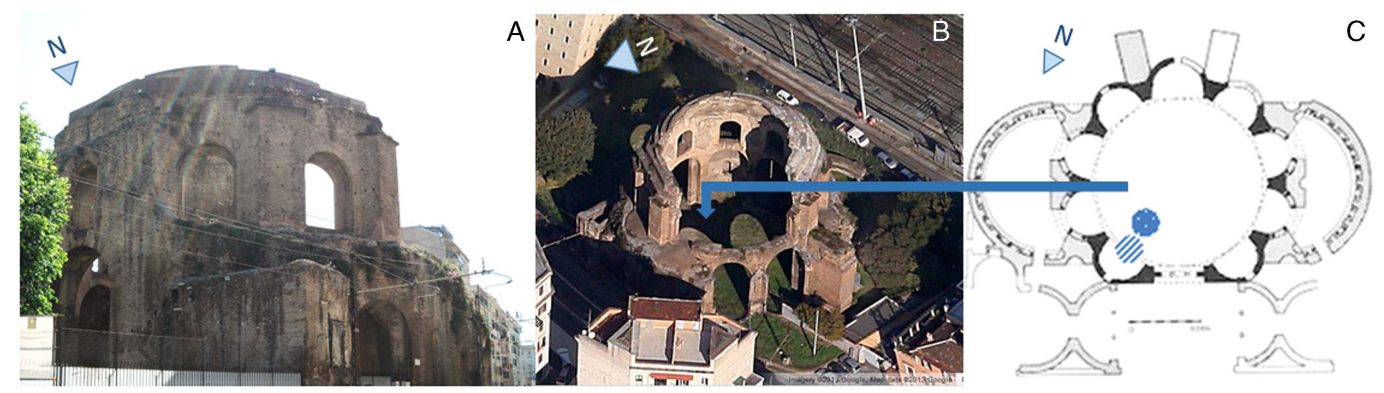

Figure 4 (A) Lateral (C 2017 Sara Nonni) and (B) aerial views (C) 2017 Google) of the remains of the Temple of Minerva Medica in Rome's city center; (C) a plan (modified from Ward-Perkins 1979) showing schematically where the excavation took place on the southwest side of the main floor: the striped dot indicates the position of the buried structure where samples TMM1, TMM2, and TMM3 were collected and the solid dot indicates the same for TMM4 and TMM5.

reproducibility tests on pozzolana mortars in the literature, this site was utilized as a preliminary test for Cryo2SoniC's overall precision. For this scope, a larger portion of mortar was used, $\sim 300 \mathrm{~g}$ sampled from the floor (OST6).

Sample ToFil was collected from a portion of the Roman masonry of Tor del Fiscale (Figure 3). The mortar was collected from the joint settled between the bricks of the external southwest wall. Close to the sampling point, a brick stamp referring to Hadrian's age (126 AD) was in place.

Five samples (TMM1, TMM2, TMM3, TMM4, and TMM5) were collected on the southwest side of the foundation walls of the Roman Temple of Minerva Medica (Figure 4). In particular, above $2 \mathrm{~m}$ under the main floor of the Temple, from the original structures of the 4th century $\mathrm{AD}$, recently excavated, three samples were collected (TMM1, TMM2, TMM3). Two other samples, TMM4 and TMM5, were collected from the walls of an older structure of the 1st century AD, laying on a deeper archaeological level (over $2.5 \mathrm{~m}$ from the main floor).

A set of anonymous samples characterized by aggregates different from pozzolana were used to compare the carbon yield from aerial mortars to the carbon yield from the pozzolana ones. Aerial mortars are here represented with numerical lab codes: 2824, 2826, 4533, 4535, 4537, 4642, 4818, 4819,4823 , and 5080 . No ${ }^{14} \mathrm{C}$ dating will be performed. Table 1 shows a summary of their different archaeological, geographical, and historical backgrounds and some basic compositional information as well. Samples are from buried and unburied archaeological structures.

\section{Characterization of the Mortars}

Petrographic analysis of the selected mortar samples was carried out in order to gain information on the composition of both aggregate and mortar components. Moreover, petrographic analyses helped to detect possible contaminant sources such as unburned limestone residues (calcinations relicts), calcareous aggregates and recrystallized calcite and/or identifying possible features of mortar degradation. Investigations were performed on mortars in thin sections $(30 \mu \mathrm{m})$ using a polarizing optical microscope (ZEISS D-7082 Oberkochen) at different magnifications $(2 \times, 10 \times, 20 \times)$ under parallel and crossed nicols.

\section{${ }^{14} \mathrm{C}$ Analysis}

The Cryo2SoniC methodology was applied to select the carbon (C) signal from the binder by means of a sequence of physical separations including steps of cryogenic breaking, 
ultrasonication, and centrifugation according to Marzaioli et al. $(2011,2013)$ and Nonni et al. (2013). This procedure is based on the experimental observation that binder carbonates are characterized by a more easily breakable structure than one of the aggregates (Marzaioli et al. 2011, 2013; Nonni et al. 2013). By gently breaking the softer binder structure, originating a suspension of fine particles characterized by a slow sedimentation velocity and collecting suspended particles, mortar purification is achievable. The applied procedure is detailed as follows:

1. Cryogenic breaking. Following the procedure reported by Nawrocka et al. (2005) and Marzaioli et al. $(2011,2013)$, mortar pieces $(\sim 5 \mathrm{~g})$ were wrapped in multiple layers of $\mathrm{Al}$ foil and submerged in liquid nitrogen until reaching a thermal equilibrium. Samples were immediately transferred into an oven at $80^{\circ} \mathrm{C}$ and kept at a constant temperature for $1 \mathrm{~min}$. After repeating this freezing/thawing cycle three times, the mortars were crumbled by hand or by applying pressure by a very gentle hammering if strongly cohesive.

2. Size selection. The produced fragments (spanning a wide range of particle sizes) were sieved keeping only material below $800 \mu \mathrm{m}$ and stored in a $75 \mathrm{~mL}$ beaker with $\sim 40 \mathrm{~mL}$ of deionized water. The system was left to settle for $12 \mathrm{hr}$.

3. First ultrasonic selection. The water portion was removed using a micropipette, followed by addition of $40 \mathrm{~mL}$ of deionized water to the beaker, and left to settle for $1 \mathrm{hr}$. An ultrasonic bath was run for $10 \mathrm{~min}$ with a Salecta Ultrason-H using high-frequency sound waves $(40 \mathrm{kHz}$, $200 \mathrm{~W})$. The watery portion was collected with a micropipette in a centrifuge tube. This first fraction may have been potentially affected by dead carbon contamination, therefore we did not use it for dating (Marzaioli et al. 2013).

4. Second ultrasonic selection. A new volume of $40 \mathrm{~mL}$ of deionized water was added to the beaker, left to settle for $1 \mathrm{hr}$ and a second ultrasonic bath was run again for $30 \mathrm{~min}$. About $30 \mathrm{~mL}$ of water suspension was collected in a centrifuge tube $(50 \mathrm{~mL})$, avoiding any agitation of the sediments.

5. Centrifugation. A centrifugation of tubes with the aqueous suspension was run at $8.0 \mathrm{krpm}$, in a rotor of $10 \mathrm{~cm}$ mean radius, for $5 \mathrm{~min}$. The watery part removed and the tubes were left ovendried overnight at a constant temperature of $80^{\circ} \mathrm{C}$. Fractions of fine powders were obtained, and a sieving test assured they were $<63 \mu \mathrm{m}$. This type of fraction is considered to be representative of the binder, although more or less significant quantities of finely grained aggregates could be found (Bakolas et al. 1998; Moropoulos et al. 2000). After this point, there was no further selection and we supposed Cryo2SoniC efficiency was enough to discriminate the binder from any unwanted carbon signals different from it.

Each sample of $40 \mathrm{mg}$ of carbonate fractions was kept in a special reaction vessel for isotope analysis, modified from McCrea (1950), with an excess of frozen $\mathrm{H}_{3} \mathrm{PO}_{4}(85 \%)$. The acid is kept into a portion of the vessel separated from the main chamber, not interacting with the sample (Figure 5). One by one the reaction vessels were first evacuated $\left(<10^{-3}\right.$ mbar $)$ to ensure the vacuum then detached from the purification line. The acid was then mixed with the binder fraction by overturning the ampulla, starting the acid digestion. A complete digestion of the carbonates was run in oven for $2 \mathrm{hr}$ at $85^{\circ} \mathrm{C}$. The content of the reaction vessels underwent a cryogenic purification from all gases potentially poisonous to the reduction step and from any amount of interfering water, by means of a vacuum line and a liquid nitrogen trap $\left(\mathrm{T}=-195.86^{\circ} \mathrm{C}\right)$, shown in Figure 5 (Marzaioli et al. 2008, 2011). A double spiral trap cryogenic line isolated the $\mathrm{CO}_{2}$ from the air and water with the $100 \%$ efficiency (Bertolini et al. 2005; 


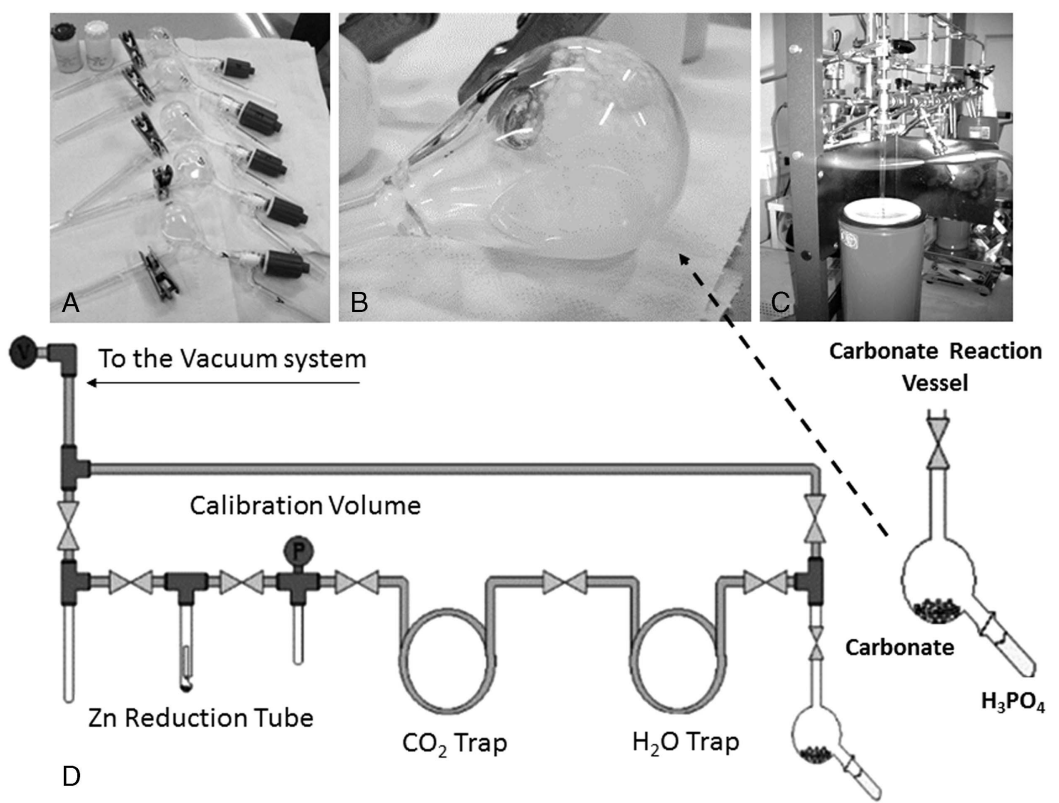

Figure 5 Scheme of the cryogenic purification line for ${ }^{14} \mathrm{C}$ sample pretreatment (Marzaioli 2011) with detailed views of the carbonate reaction vessel used for the digestion of carbonaceous materials $(\mathrm{A}, \mathrm{B}, \mathrm{D})$ and the moment of the $\mathrm{CO}_{2}$ confinement $(\mathrm{C})$.

Marzaioli 2011). The calibration chamber (fixed volume of the line; Figure 5) was calibrated by means of $\mathrm{C} \%$ standards by recording produced pressures of different kinds and amount of samples and producing a linear calibration function relating Pvol with the amount of C. Each sample $\mathrm{CO}_{2}$ pressure, measured into the calibration chamber, was finally converted into $\mathrm{C}$ mass by inverting the produced linear relationship. The collected $\mathrm{CO}_{2}$ was converted to graphite on iron powder catalyst following the zinc reduction process used at CIRCE as in Marzaioli et al. (2008). With the aim to check accuracy, reproducibility, and induced background of the line, IAEA C1 (background) and IAEA C2 (normalization; Rozanski et al. 1992) were digested and reduced to graphite following the same procedure. The reduction line background is estimated to be $(0.13 \pm 0.08$ mean value \pm standard deviation $)$ pMC leading to an apparent age of $53.0 \pm 4.6 \mathrm{kyr}$ for processed blanks of $\mathrm{C}$ mass higher than $1 \mathrm{mg} \mathrm{C}$. The contamination of the overall process corresponds to $1.2 \pm 0.3$ micrograms of modern carbon. We tried indeed also reference IAEA $\mathrm{C} 1$ and $\mathrm{C} 2$ sample Cryo2SoniC attack, not observing any statistical difference of treated vs untreated carbonaceous samples so it is plausible assuming that no extra contamination was introduced by the Cryo2SoniC procedure.

Graphite samples were measured by means of the CIRCE-AMS system to obtain the ${ }^{14} \mathrm{C}$ isotopic ratios (Terrasi et al. 2008). ${ }^{14} \mathrm{C} /{ }^{12} \mathrm{C}$ ratios were converted to ${ }^{14} \mathrm{C}$ ages and presented, according to Stuiver and Polach (1977) in calibrated (i.e. calendar) ages. Calibration was performed by means of the OxCal 4.2.4 calibration program (Bronk Ramsey and Lee 2013) using IntCal13 atmospheric calibration data set (Reimer et al. 2013). ${ }^{14} \mathrm{C}$ calibrated ages at $1 \sigma$ and $2 \sigma$ were compared to the archaeological expectations. Any sample contamination, occurring during the application of Cryo2SoniC and following steps, was contained and avoided by using brand new consumables or glassware cleaned by cycles of hydrochloric acid and distilled water to remove any eventual lime-based residues. 
As the main aim of this study was to check the reliability of the Cryo2SoniC when applied to an untouched mortar sample, no lime lump was isolated from the bulk of any mortar sample, even when easily recognizable. A further deterrent for performing a selective sampling of lime lumps was the risk to incur in an erroneous sampling of $\mathrm{CaCO}_{3}$ nodules, derived from volcanic activity (Miriello et al. 2010).

A reproducibility test was performed independently replicating the Cryo2SoniC selection procedure four times, by repeating the sampling and the Cryo2SoniC on the large sample of OST6. Four different aliquots of selected powder were obtained and dated. The resulting ${ }^{14} \mathrm{C}$ ages allowed the definition of the repetition variability for the Cryo2SoniC procedure by applying the Bayesian outlier analysis (Bronk Ramsey and Lee 2013) onto the weighted average. This procedure ends with an index of agreement corresponding to the $\chi^{2}$ test probability onto the weighted average as a position estimator of the $\mathrm{F}^{14} \mathrm{C}$ studied distribution.

\section{Characterization of Fractions Obtained by Cryo2SoniC}

An ultimate test on isolated fractions was performed by a sieving test and observations via scanning electron microscopy (SEM) to check both the minimum and average size collected, and the morphology of the selected particles.

A sieving test was performed on all fractions using a traditional $63 \mu \mathrm{m}$ sieving. SEM-EDS analysis was performed with an FEI-Quanta 400 scanning electron microscope, coupled with an energy dispersive X-ray spectroscope operated at $20 \mathrm{kV}$, on metallized samples. Metallization was carried out with an Emitech K550X thinly layering Au on calcite powder. The magnification was up to $50,000 \times$ due to the bad conductivity of the sample's surface during image acquisition. SEM analysis was performed on fractions OST6 D, TMM4, 4818, 4819, and 4537, isolated by Cryo2SoniC from the original mortar. A lack of material did not allow a systematic test on all fractions.

\section{RESULTS AND DISCUSSION}

\section{Mortar Characterization}

Petrographic observations on thin sections confirmed the presence of volcanic glass and pozzolana aggregates. A copious presence of leucite minerals and a minor presence of zeolites, orthopyroxene, green hornblende, olivine, feldspar, and biotite was identified (Table 1). All samples had highly crystalline pozzolana aggregates full of chart-wheel leucite crystals (Figure 6A, 6B) while ToFil had phenocrysts of leucite dispersed into the matrix with diameters up to $8 \mathrm{~mm}$ (Figure 6D). It is well known that pyroclastic aggregates tend to chemically react at their interfaces with lime (Sanchez-Moral et al. 2005), developing calcium-silicate-hydrate (CSH) gel and alumina, ferric oxide, mono sulphate (AFm) phases, typical components of a hydraulic cement (Femy et al. 2003; Richardson 1999). It is possible that the occurring "reaction rims" along the surfaces of the pozzolana fragments towards the binder paste consisted of species of calcium silicate hydrate giving our samples hydraulic properties, but this was undetectable by a petrographic microscope (Idorn and Thaulow 1983; Massazza 1993). On the contrary, the presence of spathic crystals of secondary calcite was easily detectable both inside the tuff fragments and the binder. Different levels of contamination found among all the pozzolana samples (Table 1, Figure 7). Newly formed calcite depositions represent a source of contamination for the final dating, either for rejuvenation or aging, depending on its origin. Specifically, relevant calcite depositions were observed in ToFil and in all samples from the Temple of Minerva Medica (Figure 6). 
Table 1 For each sample is listed: geographical provenance, age attribution and petrographic features as binder/aggregate ratio (B/A), aggregate composition and presence of secondary calcite or lime lumps. Relative abundance of each mineral phase or component within each sample is given using symbol $\mathrm{X}$ to indicate major phases and + for minor ones.

\begin{tabular}{|c|c|c|c|c|c|c|}
\hline Sample & Provenance & Age attribution & $\mathrm{B} / \mathrm{A}$ & Aggregates composition & Secondary calcite & Lime lumps \\
\hline OST6 & Italy & $123-126$ AD & $1: 2$ & $\begin{array}{l}\text { Volcanic Glass XXX, leucite XXX, zeolite XX, orthopyroxene X, hornblende }++ \text {, } \\
\text { olivine }++ \text {, feldspar }+ \text {, biotite }+\end{array}$ & $\mathrm{X}$ & $\mathrm{X}$ \\
\hline $\mathrm{OST}^{\circ}$ & Italy & & $1: 2$ & & $\mathrm{X}$ & $\mathrm{X}$ \\
\hline OST6 " & Italy & & $1: 2$ & & $\mathrm{X}$ & $\mathrm{X}$ \\
\hline OST6 “" & Italy & & $1: 2$ & & $\mathrm{X}$ & $\mathrm{X}$ \\
\hline OST4 & Italy & & $1: 2$ & & +++ & $\mathrm{X}$ \\
\hline TOFI1 & Italy & & $1: 2$ & $\begin{array}{l}\text { Volcanic Glass XXX, leucites XXX, zeolites X, amphibole X, olivine X, } \\
\text { plagioclase X, orthopyroxene X, green hornblende X, biotite }+\end{array}$ & $\mathrm{XX}$ & $\mathrm{XXX}$ \\
\hline TMM1 & Italy & 4th century AD & $1: 3$ & $\begin{array}{l}\text { Volcanic glass XXX, leucite XX, zeolites } \mathrm{X} \text {, biotite }++ \text {, muscovite }++ \\
\text { clinopyroxene }++ \text {, plagioclase }+, \text { quartz }+\end{array}$ & $\mathrm{XXX}$ & + \\
\hline TMM2 & Italy & & $1: 3$ & $\begin{array}{l}\text { Volcanic glass XXX, leucite } \mathrm{XXX} \text {, zeolite } \mathrm{XXX} \text {, muscovite }+++ \text {, biotite }++ \text {, } \\
\text { clinopyroxene }+ \text {, plagioclase }+\end{array}$ & $\mathrm{XXX}$ & ++ \\
\hline TMM3 & Italy & & $1: 3$ & & $\mathrm{XXX}$ & + \\
\hline TMM4 & Italy & 1st century AD & $1: 3$ & $\begin{array}{l}\text { Volcanic glass XXX, leucite } \mathrm{XXX} \text {, zeolite } \mathrm{XX} \text {, quartz } \mathrm{X} \text {, biotite }+ \text {, } \\
\text { clinopyroxene }+ \text {, plagioclase }+\end{array}$ & $\mathrm{XXX}$ & + \\
\hline TMM5 & Italy & & $1: 3$ & $\begin{array}{l}\text { Volcanic glass XXX, leucite XXX, zeolite XX, quartz X, biotite }++ \text {, } \\
\text { clinopyroxene }+ \text {, plagioclase }+\end{array}$ & $\mathrm{XXX}$ & + \\
\hline 5077 & Italy & 13th century AD & $1: 2$ & Incomplete burned limestone residues $\mathrm{X}$, limestone $\mathrm{XX}$ & $\mathrm{XX}$ & $\mathrm{XXX}$ \\
\hline 4818 & Poland & 15 th -16 th century AD & $1: 2$ & Quartz sand XXX, cherts X, granitoid + , sandstone + , mudstone + , feldspars + & $\mathrm{X}$ & XX \\
\hline 4819 & Poland & & $1: 2$ & & $\mathrm{X}$ & $\mathrm{XX}$ \\
\hline 4537 & Poland & & $1: 2$ & & $\mathrm{X}$ & - \\
\hline 4823 & Poland & & $1: 2$ & & $\mathrm{X}$ & - \\
\hline 2824 & Italy & 1st-2nd century AD & $1: 3$ & $\begin{array}{l}\text { Calcite XX, quartz XX, metamorfic quartz XX, sandstone } \mathrm{X} \text {, plagioclase }++ \text {, } \\
\text { perthite }++ \text {, muscovite }+\end{array}$ & ++ & - \\
\hline 2826 & Italy & 14 th century AD & $1: 3$ & $\begin{array}{l}\text { Quartz XX, metamorphic quartz XX, spatic calcite } \mathrm{X} \text {, sandstone } \mathrm{X} \text {, mudstone }+ \text {, } \\
\text { perthite }++ \text {, bioclast }+\end{array}$ & + & - \\
\hline 5080 & Italy & 11 th -14 th century AD & $1: 3$ & Incomplete burned limestone residues $\mathrm{X}$, limestone $\mathrm{XX}$ & $\mathrm{XX}$ & $\mathrm{X}$ \\
\hline 4642 & Israel & 1st-2nd century BC & $1: 3$ & Foraminiferous limestone $\mathrm{XXX}$, shells $\mathrm{X}$, dolomite +++ , flint + & - & - \\
\hline 4533 & Israel & 1 st century $\mathrm{BC}$ & $1: 3$ & Limestone $\mathrm{X}$, dolomite $\mathrm{X}$, flint $\mathrm{X}$, shells ++ , charcoal + & - & - \\
\hline 4535 & Israel & & 1.3 & & - & - \\
\hline
\end{tabular}



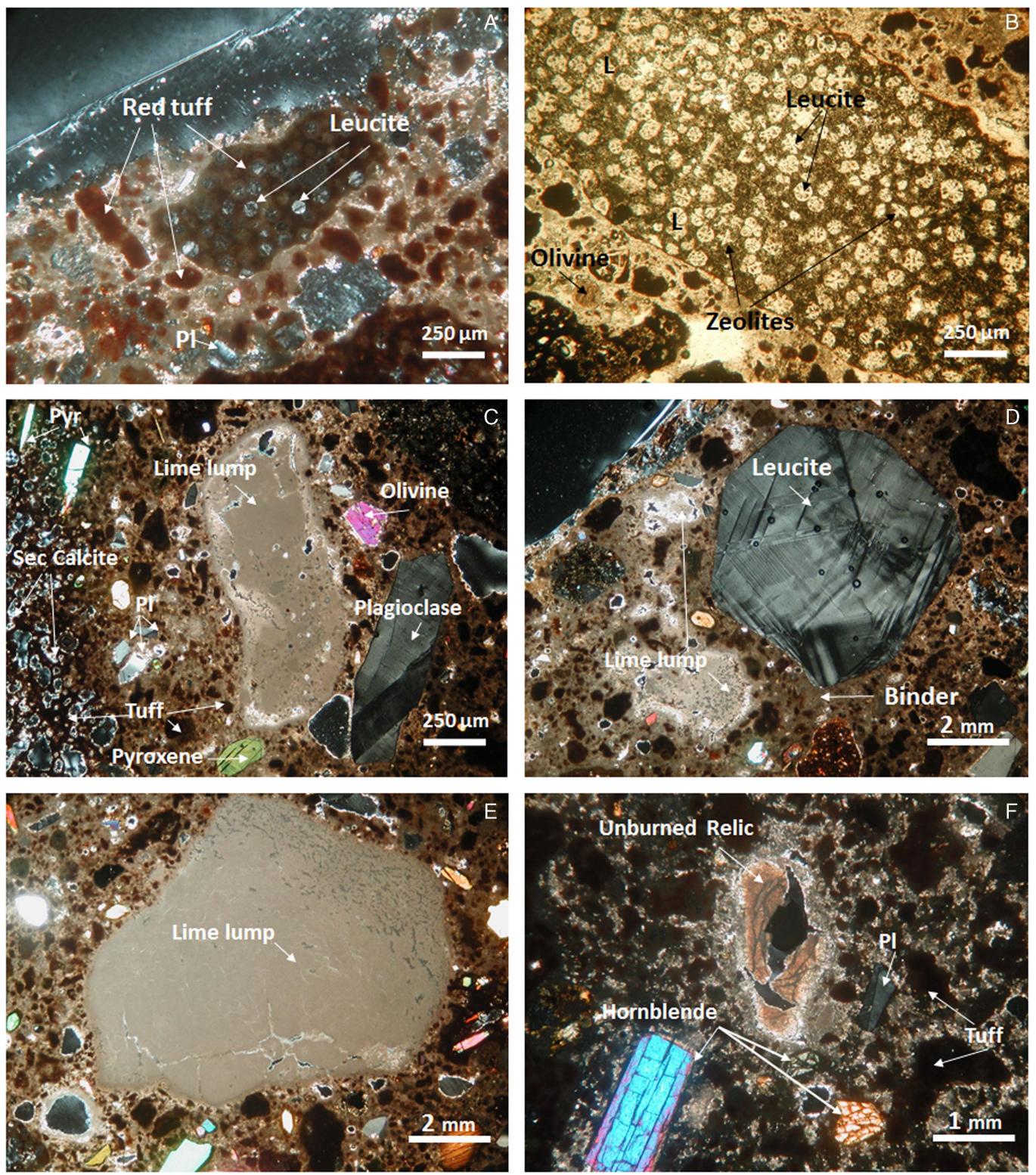

Figure 6 Thin sections of pozzolana mortars under parallel (B) and crossed nicols (A, C, D, E, F) showing main mineralogical components and interesting features like phenocrysts of leucite (D), leucite cartwheel (B), unburned calcination relics (F), and different size of lime lumps (C, D, E); A: OST6; B: TMM 3; C-F: ToFi.

In ToFil and OST6, the presence of calcareous residues is localized mainly into the aggregate portion (Figures 6C and 7D), and it could be attributable to ascended movements of magmatic fluids through a limestone basement (Rittmann 1933; Jackson and Marra 2006) or to atmospheric activity affecting the pozzolana grains before its use as a mortar aggregate (i.e. raw materials stored outdoor). Samples from the Temple of Minerva Medica revealed a different and massive contamination of secondary calcite: the newly formed calcite crystals had either a phenocryst, spatic and micritic shape, massively filling up all voids of the mortar and substituting up to the $80 \%$ of the 

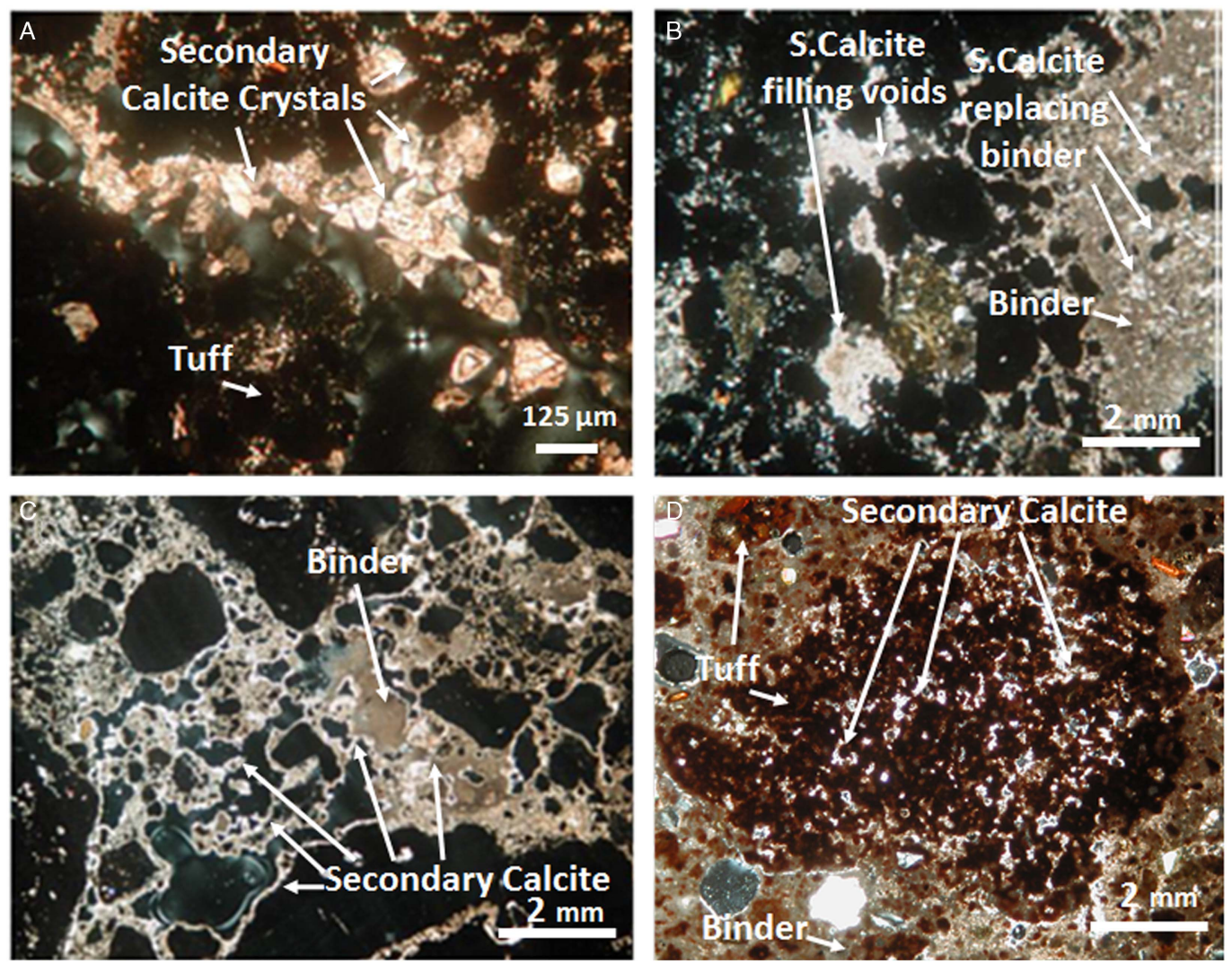

Figure 7 Secondary calcite depositions strongly affecting mortars from Temple of Minerva Medica and Tor del Fiscale: (A) calcite crystals inside tuff voids (TMM4); in (B) and (C) calcite crystals completely filling the pores of the sample (B: TMM5) and substituting binder matrix (TMM1); in (D) calcite crystals grown mainly inside pozzolana voids and porosity (ToFi1; $10 \times$ crossed nicols).

original binder (Figure 7). Bigger crystals of secondary calcite, grown on the cavities' surfaces, suggest a very slow geological episode involving the interaction of the mortar with a moving source of hard water (Figure 7A). The origin of this deposition is less likely to be attributed to meteoric origins (buried environment) and more likely to be attributed to groundwater interactions. Evidences of rising groundwater activities are attested for many sites in Rome including the area where the Temple of Minerva Medica was built (Ventriglia 1971).

A binder/aggregate ratio (B/A) of 1:2 was observed for Ostia and Tor Del Fiscale samples while a lower ratio of 1:3 was observed on Temple of Minerva Medica samples. A significant presence of lime lumps was found in ToFil, covering a $45 \%$ of the whole binder portion. In ToFil, lime lumps reached up to $10 \mathrm{~mm}$ in diameter and some of them carried traces of calcination relics (Figure 6, C-F). A lower presence of lime lumps was attested for OST6 and TMM with respectively a 30\% and $10 \%$ of the whole binder portion. Although a perfectly formed lime lump is considered free from dead C contamination (Pesce et al. 2009, 2012; Marzaioli et al. 2013; Ringbom et al. 2014; Lubritto et al. 2015), in this study, no lime lump was isolated from the bulk or dated separately.

The samples used for the comparison of yielded carbon can be roughly divided into two groups: mortars with a quartz aggregates (AQ: 4818, 4819, 4823) and mortars with a calcareous 
aggregate (AC: 2824, 2826, 5077, 5080, 4533, 4535, 4537, 4642). Mortars with quartz aggregates had quartz sands, granitoid, sandstone, chert, mudstone, and feldspars (details in Table 1). Mortars with calcareous aggregates had limestone, dolomite, flint, shell, and foraminiferous limestone. Each of these groups had both mortars with a B/A ratio of 1:3 and 1:2. Samples 4818, 4819, 5077, and 5080 had lime lumps while almost all of them had slight occurrence of secondary calcite (Table 1).

\section{Physical Characterization of Cryo2SoniC Fractions}

Particle size dimension for all fractions obtained by Cryo2SoniC by traditional sieving was lower than $63 \mu \mathrm{m}$. On fractions OST6 D, TMM4, 4818, 4819, 4537 a collection of a series of backscattered electron images by SEM was performed. Images captured at 3, 2, and $1 \mu \mathrm{m}$ showed particles mean size was above $1 \mu \mathrm{m}$ and a minimum size below this value (Figure 8). An overall roundness was observed for particles in OST6 (pozzolana aggregate), 4537 (calcareous
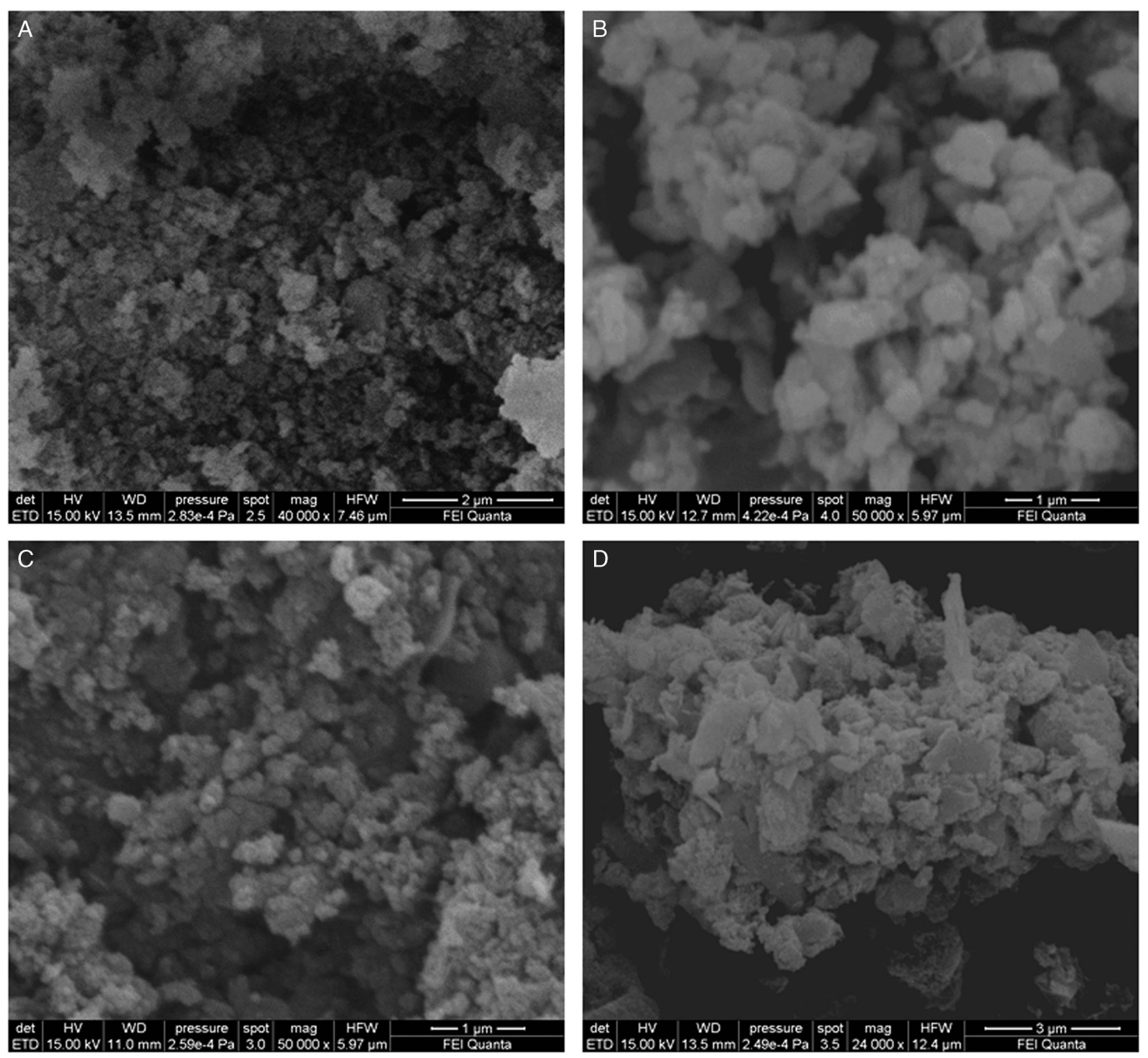

Figure 8 SEM images of fractions selected by Cryo2SoniC captured at high magnifications, which show an overall average size particle of $1 \mu \mathrm{m}$ and a minimum size below: (A) sample 4537; (B) sample 4119; (C) sample OST6; (D) sample TMM4. Samples A, B, C have particles with an overall rounded shape, while D shows a mix of particles with different shapes (both rounded and angular) and size (from sub-micrometric up to $3 \mu \mathrm{m}$ ). 
aggregate), 4818, and 4819 (quartz aggregate). Particle roundness and sub-micrometric dimension suggest a chemical origin (round particles originated from colloids) more than a mechanical one (sharper and pointed shapes). The chemical process of producing colloids, which flocculate and regrow generating finer particles, has been demonstrated for sub-aerial media (Wilson and Spengler 1996; Seinfeld and Pandis 2006) and for aqueous media (Davis and Kent 1990; Salama 2000; Ortega et al. 2012; Gal et al. 2013).

On the isolated fraction from TMM4, SEM images disclosed particles with various shapes and sizes. In Figure $8 \mathrm{D}$, the presence of bigger particles $(\sim 3 \mu \mathrm{m}$ diameter $)$ with angular shapes is highlighted for TMM4, probably attributable to micrometric volcanic glass fragments derived from the breakage of the pozzolana aggregate. None of the suspensions excluded the presence of crystals of secondary calcite a priori, when dimensionally similar to the calcite from the binder $(\sim 1 \mu \mathrm{m})$.

\section{Carbon Yield in Pozzolana Mortars}

Independently from the type of aggregate, mortars with a similar B/A ratio should give similar amounts of $\mathrm{C}$ extracted per unit of mass undergone during pretreatment (Cryo2SoniC). This is true if all the portions of binder are made of the same amount of carbonates, but it cannot be valid for pozzolana mortars, where a variable presence of hydraulic compounds in the binder should lead to a lower availability of carbonate suitable for dating. Portions of binder reacting with its volcanic aggregate form calcium-silicate-hydrate gel and alumina, ferric oxide, mono sulphate phases at the binder/pozzolana interfaces. These types of materials cannot be carriers of the atmospheric signal like the binder itself, even if they look similar both at a macroscopic or microscopic level. As shown in Table 3, from each $40 \mathrm{~g}$ of powder isolated by Cryo2SoniC from a pozzolana mortar, was obtained on average, about half of the carbon developed from fractions collected from mortars with similar B/A ratio but different type of aggregate.

Furthermore, it was observed that for same B/A ratios, mortars with quartz aggregates or calcareous aggregates, developed a similar amount of $\mathrm{C}$ independently from the type of aggregate (Table 2). The presence of lime lumps, usually an important advantage and a precious resource for ${ }^{14} \mathrm{C}$ dating, did not have the same constant impact on the total amount of $\mathrm{C}$ yielded by the bulk of mortar. ToFil was, among all pozzolana mortars, the sample with the higher proportion of lime lumps above the binder, however, its yield of carbon did not stand out from the others with similar B/A ratio as it happened instead for samples of aerial mortar 4818, 4819, 5077.

It is good to recall that the percentage of carbon developed from a Cryo2SoniC fraction is highly dependent not only from the original B/A but also from the hardness and chemistry of the aggregate composing a mortar. Highly fragile carbonate aggregates producing sub-particles of micrometric dimensions could be collected into the Cryo2SoniC portion changing the total $\%$ C, as well as particles of secondary calcite (see samples 5077 and 4642).

\section{${ }^{14} \mathrm{C}$ Dating}

A set of archaeological pozzolana mortars of known age has been dated to test the reliability and efficiency of the Cryo2SoniC protocol on the selection of the binder signal.

${ }^{14} \mathrm{C}$ results are summarized in Table 3, where each value shows the age found dating the fraction collected by Cryo2SoniC protocol. Experimental results were compared to archaeological references: a historical attribution for the mortars from Temple of Minerva Medica (4th century AD), and some Hadrian's age brick stamps (123-126 AD) found in the proximity of the 
Table 2 The amount of $\mathrm{C}(\mathrm{mg})$ obtained from acid leaching of $40 \mathrm{mg}$ of fractions collected by Cryo2SoniC is shown. For each sample, the binder/aggregate ratio (B/A) and the mortar type is given: $\mathrm{P}$, pozzolana mortars; AC aerial mortars with calcareous aggregates; AQ aerial mortars with quartz aggregates. The value of $\mathrm{C}(\mathrm{mg})$ has been rounded off to two decimals. The average amount of the $\mathrm{C}(\mathrm{mg})$ from pozzolana mortars and not pozzolana mortars allows an estimate of the $\% \mathrm{C}$ extracted from each group.

\begin{tabular}{|c|c|c|c|c|c|}
\hline Sample & Type & $\mathrm{B} / \mathrm{A}$ ratio & Mass of $\mathrm{C}(\mathrm{mg})$ & $\begin{array}{l}\text { Average } \\
\text { mass of } \mathrm{C}(\mathrm{mg})\end{array}$ & $\begin{array}{l}\% \mathrm{C} \\
\text { yield }\end{array}$ \\
\hline OST6 & $\mathrm{P}$ & $1: 2$ & 2.48 & 1.75 & 4.38 \\
\hline OST6 ‘ & $\mathrm{P}$ & $1: 2$ & 1.57 & & \\
\hline OST6 " & $\mathrm{P}$ & $1: 2$ & 2.15 & & \\
\hline OST6 " & $\mathrm{P}$ & $1: 2$ & 0.86 & & \\
\hline OST4 & $\mathrm{P}$ & $1: 2$ & 1.64 & & \\
\hline TOFI1 & $\mathrm{P}$ & $1: 2$ & 1.82 & & \\
\hline TMM1 & $\mathrm{P}$ & $1: 3$ & 1.41 & 1.11 & 2.78 \\
\hline TMM2 & $\mathrm{P}$ & $1: 3$ & 1.52 & & \\
\hline TMM3 & $\mathrm{P}$ & $1: 3$ & 1.48 & & \\
\hline TMM4 & $\mathrm{P}$ & $1: 3$ & 0.59 & & \\
\hline TMM5 & $\mathrm{P}$ & $1: 3$ & 0.55 & & \\
\hline 5077 & $\mathrm{AC}$ & $1: 2$ & 3.45 & 4.13 & 10.32 \\
\hline 4818 & $\mathrm{AQ}$ & $1: 2$ & 4.16 & & \\
\hline 4819 & $\mathrm{AQ}$ & $1: 2$ & 5.11 & & \\
\hline 4537 & $\mathrm{AC}$ & $1: 2$ & 3.07 & & \\
\hline 4642 & $\mathrm{AC}$ & $1: 2$ & 4.85 & & \\
\hline 2824 & $\mathrm{AC}$ & $1: 3$ & 1.82 & 2.15 & 5.37 \\
\hline 2826 & $\mathrm{AC}$ & $1: 3$ & 0.99 & & \\
\hline 5080 & $\mathrm{AC}$ & $1: 3$ & 2.40 & & \\
\hline 4823 & $\mathrm{AQ}$ & $1: 3$ & 1.72 & & \\
\hline 4533 & $\mathrm{AC}$ & $1: 3$ & 2.47 & & \\
\hline 4535 & $\mathrm{AC}$ & 1.3 & 3.15 & & \\
\hline
\end{tabular}

mortars, for the sites of Ostia Marina and Tor Del Fiscale. The brick stamps were here considered as a terminus post quem or a lower limit for the absolute dating.

As shown in Figure 9, experimental dates were in agreement with the archaeological expectations for mortars from sites of Ostia and Tor Del Fiscale, both successfully dated to the era of Emperor Hadrian. Cryo2SoniC demonstrated to effectively isolate the binder signal from potential sources of aging, like unburned limestone relicts seen in ToFil, and secondary calcite depositions inside pozzolana grains variably affecting ToFil as well as OST4 and OST6.

A bias of thousands of years was found for the attributed chronologies for samples from Temple of Minerva Medica (Figure 10). The aging effect from this site appears to be more significant with the increased depth of the mortar from the ground level. TMM1, TMM2, and TMM3 were about 800 years older than the attribution, while for TMM4 and TMM5 the bias was about 2000 years. The cause of this indisputable aging effect could be attributed to a massive presence of secondary calcite deposition filling all porosity of the mortar as well as extensively replacing the original binder matrix (Figure 7). These massive secondary calcite depositions are probably the results of a known groundwater activity (Ventriglia 1971). In total amount of carbon extracted from the fraction isolated by Cryo2SoniC, only a minimal part was from the 
Table $3{ }^{14} \mathrm{C}$ dates of mortars from Ostia Marina and repetitions (OST4 and OST6 serie), Tor Del Fiscale (ToFil) and Temple of Minerva Medica (TMM samples). Calendar ages at $1 \sigma$ (68.2\% probability) and $2 \sigma(95.4 \%$ probability) with archaeological references are reported following Stuiver and Polach (1977). Bold text highlights the results matching the expected dates (archaeological reference).

\begin{tabular}{|c|c|c|c|c|}
\hline \multirow[b]{2}{*}{ Sample } & \multirow{2}{*}{$\begin{array}{l}{ }^{14} \mathrm{C} \text { age } \\
\text { (yr BP) }\end{array}$} & \multicolumn{2}{|c|}{ Calibrated age } & \multirow{2}{*}{$\begin{array}{l}\text { Archaeological } \\
\text { references }\end{array}$} \\
\hline & & $1 \sigma$ & $2 \sigma$ & \\
\hline OST4 & $1860 \pm 30$ & $\begin{array}{l}90-100 \mathrm{AD}(1.9 \%) \\
125-215 \mathrm{AD}(66.3 \%)\end{array}$ & $80-230 A D(95.4 \%)$ & 123-126 AD \\
\hline OST6 & $1880 \pm 70$ & $60-230 \mathrm{AD}(68.2 \%)$ & $\begin{array}{l}40 \mathrm{BC}-260 \mathrm{AD}(\mathbf{8 9 . 4} \%) \\
275-330 \mathrm{AD}(6.0 \%)\end{array}$ & \\
\hline OST6' & $1880 \pm 45$ & $\begin{array}{l}70-170 \mathrm{AD}(60.0 \%) \\
190-210 \mathrm{AD}(8.2 \%)\end{array}$ & $30-240 \mathrm{AD}(95.4 \%)$ & \\
\hline OST6" & $1960 \pm 50$ & $40 B C-80 A D(68.2 \%)$ & $\begin{array}{l}96 \mathrm{BC}-140 \mathrm{AD}(\mathbf{9 4 . 0} \%) \\
150-170 \mathrm{AD}(0.7 \%) \\
195-210 \mathrm{AD}(0.7 \%)\end{array}$ & \\
\hline OST 6", & $1920 \pm 40$ & $\begin{array}{l}30-40 \text { AD }(6.7 \%) \\
50-130 \text { AD }(61.5 \%)\end{array}$ & $\begin{array}{l}20 B C-10 B C(1.1 \%) \\
2 B C-220 A D(94.3 \%)\end{array}$ & \\
\hline ToFil & $1880 \pm 60$ & $70-210 A D(68.2 \%)$ & $\begin{array}{l}20 B C-10 B C(0.6 \%) \\
2 B C-260 A D(92.9 \%) \\
300-320 A D(1.8 \%)\end{array}$ & $126 \mathrm{AD}$ \\
\hline TMM1 & $2680 \pm 70$ & $900-800 B C(68.2 \%)$ & $1020-755$ BC $(94.8 \%)$ & 4th century AD \\
\hline TMM2 & $2570 \pm 35$ & $\begin{array}{l}800-755 B C(59.7 \%) \\
680-670 B C(4.4 \%) \\
610-600 B C(4.1 \%)\end{array}$ & $\begin{array}{l}809-740 B C(64.5 \%) \\
690-665 B C(7.6 \%) \\
640-550 B C(23.3 \%)\end{array}$ & \\
\hline TMM3 & $2440 \pm 40$ & $\begin{array}{l}740-690 \mathrm{BC}(16.6 \%) \\
660-650 \mathrm{BC}(5.2 \%) \\
550-400 \mathrm{BC}(46.4 \%)\end{array}$ & $\begin{array}{l}760-680 B C(22.5 \%) \\
670-605 B C(14.5 \%) \\
600-410 B C(58.3 \%)\end{array}$ & \\
\hline TMM4 & $3570 \pm 60$ & $\begin{array}{l}2020-1990 \mathrm{BC}(8.8 \%) \\
1980-1875 \mathrm{BC}(46.5 \%) \\
1840-1820 \mathrm{BC}(7.5 \%) \\
1800-1780 \mathrm{BC}(5.4 \%)\end{array}$ & $\begin{array}{l}2130-2060 B C(4.1 \%) \\
2050-1740 B C(91.0 \%) \\
1710-1700 B C(0.3 \%)\end{array}$ & 1st century AD \\
\hline TMM5 & $3790 \pm 80$ & $\begin{array}{l}2350-2130 \mathrm{BC}(60.9 \%) \\
2090-2050 \mathrm{BC}(7.3 \%)\end{array}$ & $\begin{array}{l}2470-2020 B C(95.1 \%) \\
1990-1980 B C(0.3 \%)\end{array}$ & \\
\hline
\end{tabular}

binder, while it was largely from carbonates derived from precipitation secondary calcite crystals of geological limestone diluted in the underground springs during years of variable underground floods. The aging bias observed on samples followed this theory: mortars collected at a lower level of burial (TMM4, TMM5 3 m under the main floor), had withstood more or more frequent floods than the three mortars collected at upper levels (TMM1, TMM2, TMM3 2 $\mathrm{m}$ under the main floor).

A further comparison to verify the reproducibility of the pretreatment Cryo2SoniC method for pozzolana mortars was performed and results on OST6 are shown in Table 3. The observed combined variability (i.e. error of the weighted mean) of the ${ }^{14} \mathrm{C}$ age over the four replicates of OST6 led to $1945 \pm 20 \mathrm{yr}$ BP (i.e. about $0.3 \%$ on the $\mathrm{F}^{14} \mathrm{C}$ ) comparable with the machine repeatability. The agreement index produced by the $\chi^{2}$ test onto the measured $\mathrm{F}^{14} \mathrm{C}$ values was $91.2 \%$.

\section{CONCLUSIONS}

This study allows us to verify that the percentage of $\mathrm{C}$ yields from mortars with pozzolana aggregates are less than half of those obtained from mortars with aggregates different from pozzolana. If the same amount of binder extracted from a mortar results in a lower quantity of 


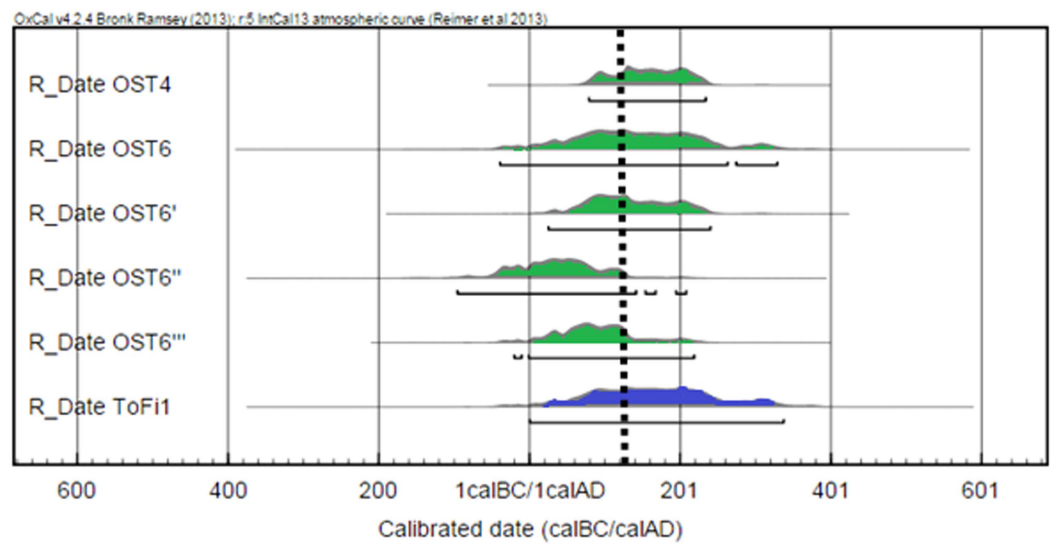

Figure 9 Calibrated ages for pozzolana mortar samples from Ostia and Tor del Fiscale matching their archaeological attributions (123-126 AD).

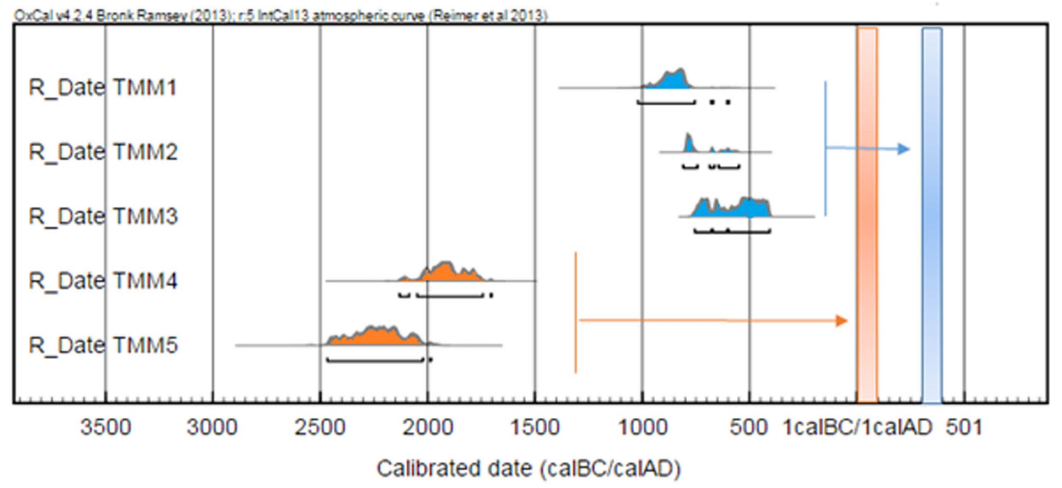

Figure 10 Calibrated ages for pozzolana mortars from Temple of Minerva Medica and their relative historical references: 1st century AD for TMM1, TMM2, and TMM3 and 4th century AD for TMM4 and TMM5. The graph shows strong aging effects due to dead carbon contamination of secondary calcite depositions of geological origin (i.e. groundwater).

carbon, a higher amount of original mortar is required to undergo to the Cryo2Sonic or equivalent selection methods.

Moreover, the Cryo2SoniC procedure was demonstrated to be a reliable pretreatment method to select a fraction of calcite suitable for dating pozzolana based mortars, moderately affected by dead carbon contamination: reliable and reproducible results on pozzolana mortars in agreement with the archaeological attributions were obtained on samples from Tor del Fiscale and Ostia. The protocol showed good reproducibility within the same sample, producing consistent dating within four complete independent replicates. The selection of the carbonates from the binder portion was satisfactory, leading to the discriminating of these from carbonates of calcareous components that would potentially affect the final dating, such as unburned limestone residues and secondary calcite of atmospheric origin.

The overall presence of sub-micrometric and rounded particles within the fractions isolated by Croy2SoniC and checked by SEM, suggests that the Cryo2SoniC could be an effective 
procedure to select calcite grains originated by crystal nucleation and/or chemical growth (slake lime carbonation). As well, a total absence of contaminant particles of equivalent dimensions of those of the binder, cannot be always guaranteed. This happened on samples of Temple of Minerva Medica where a massive contamination of secondary calcite extensively replaced the original $\mathrm{CaCO}_{3}$ and led to older ages. The procedure showed a failure to identify the right portion to date. This failure could be attributed to a scarce content of original binder compared to a massive presence of newly formed calcite crystals, dimensionally comparable to those to select. The binder substitution with secondary calcite was due to prolonged and recurrent ground water interactions, therefore it is strongly suggested to always perform preventive thin sections analysis on samples from buried contexts. Also, performing Cryo2SoniC and ${ }^{14} \mathrm{C}$ dating on mortar with an extensive substitution of the original binder, or from sites with known ground water activity, it is to be avoided.

\section{ACKNOWLEDGMENTS}

Special thanks to Dr Danuta Michalska from Adam Mickiewicz University of Poznan, Dr Andrea Macchia, Dr Salvo Barrano and Dr Laura Sadori from the University of Rome Sapienza, Dr Alessandro Turci from University of Bologna and Dr Maria Erzilia Loreti from the Archaeological Superintendency for providing samples and, most of all, for believing in this research.

\section{REFERENCES}

Al-Bashaireh K. 2013. Plaster and mortar radiocarbon dating of Nabatean and Islamic structure, South Jordan. Archaeometry 55(2):329-54.

Ambers J. 1987. Stable carbon isotope ratios and their relevance to the determination of accurate radiocarbon dates for lime mortars. Journal of Archaeological Sciences 14(6):569-76.

Bakolas A, Biscontin G, Moropoulou A, Zendri E. 1998. Characterization of structural byzantine mortars by thermogravimetric analysis. Thermochimica Acta 321:151-160.

Barbera M, Di Pasquale S, Palazzo P. 2007. Roma, studi e indagini sul cd. Tempio di Minerva Medica. FOLD\&R Fasti On Line Documents \& Research 91:1-21.

Baxter MS, Walton A. 1970. Radiocarbon dating of mortars. Nature 225(5236):937-8.

Bertolini T, Rubino M, Lubritto C, D’Onofrio A, Marzaioli F, Passariello I, Terrasi F. 2005. Optimized sample preparation for isotopic analyses of $\mathrm{CO}_{2}$ in air: a systematic study of precision and accuracy dependence on driving variables during $\mathrm{CO}_{2}$ purification process. Journal of Mass Spectrometry 40(8): 1104-8.

Biasci A. 2000. Il padiglione del "Tempio di Minerva Medica" a Roma: struttura, tecniche di costruzione e particolari inediti. Science and Technology for Cultural Heritage 9(1-2):67-8.

Bronk Ramsey C, Lee S. 2013. Recent and planned developments of the program OxCal. Radiocarbon 55(2-3):720-30.

Callebaut K, Elsen J, Van Balen K, Viaene W. 2001. Nineteenth-century hydraulic restoration mortars in the Saint Michael's Church (Leuven, Belgium).
Natural Hydraulic lime or cement. Cement and Concrete Research 31:397-403.

Cazalla O, Rodriguez-Navarro G, Sebastian E, Cultrone G, De la Torre MJ. 2000. Aging of lime putty: effects on traditional lime mortar carbonation. Journal of the American Ceramic Society 83:1070-6.

David M, Pellegrin A, Turci M. 2009. Ostia (Roma). Ocnus 17:198-202.

David M, Turci M. 2011. Nuove osservazioni da recentiindaginiostiensi, Atti del XVI Colloquiodell'Associazione italiana per lo studio e la conservazione del mosaico (Palermo, March 2010). Testacea Spicata Tuburtina, Tivoli. 267-75.

David M, Gonzales X. 2011. Opus doliare e nuovi bolli laterizidall'insula IV, IX di Ostia, Actes $d u$ Congres de la Societe Francaise d'Etude de la Ceramique Antique and Gaule (SFECAG), (Arles June 2011). Marsiglia 2011:389-96.

David M, Carinci M, Graziano SM, De Togni S, Pellegrino A, Turci M. 2014. Nuovi dati e argomenti per Ostia tardo-antica dal Progetto Ostia Marina. OstiaAntica - Varia. Melanges de L'Ecole francaise de Rome - Antiquite. 1-22.

Davis JA, Kent DB. 1990. Surface complexation modeling in aqueous geochemistry. MineralWater Interface Geochemistry. Rev. Mineral. 23:177-260.

Delibrias G, Labeyrie J. 1964. Dating of old mortars by the carbon-14 method. Nature 201(4920):742.

De Rossi GM. 1981. Torri medioevali della campagna Romana. Rome: Newton Compton. p 331-4.

El-Turki A, Ball RJ, Allen GC. 2007. The influence of relative humidity on structural and chemical 
changes during carbonation of hydraulic lime. Cement and Concrete Research 37(8):1233-40.

Esposito D. 1998. Tecniche costruttive murarie medievali: murature "a tufelli" in area romana. L'Erma di Bretschneider: 36-7.

Femy C, Brough AR, Taylor HFW. 2003. The C-S-H gel of Portland cement mortars: Part I. The interpretation of energy-dispersive X-ray microanalyses from scanning electron microscopy, with some observations on C-S-H, AFm and AFt phase compositions. Cement and Concrete Research 33(9):1389-98.

Folk RL, Valastro S Jr. 1976. Successful technique for dating of lime mortar by carbon-14. Journal of Field Archaeology 3(2):203-8.

Gal A, Habraken W, Gur D, Fratzl P, Weiner S, Addali L. 2013. Calcite crystal growth by a solidstate transformation of stabilized: amorphous calcium carbonate nanospheres in a hydrogel. Angewandte Chemie 52:4867-8-70.

Genestar C, Pons C. 2003. Ancient covering plaster mortars from several convents and Islamic and Gothic palaces in Palma de Mallorca (Spain): analytical characterisation. Journal of Cultural Heritage 4(4):291-8.

Goslar T, Nawrocka D, Czernik J. 2009. Foraminiferous limestone in ${ }^{14} \mathrm{C}$ dating of mortar. Radiocarbon 51(2):857-66.

Hajdas I, Trumm J, Bonanni G, Biechele C, Maurer M, Wacker L. 2012. Roman ruins as an experiment for radiocarbon dating of mortar. Radiocarbon 54(3-4):897-903.

Hale J, Heinemeier J, Lancaster L, Lindroos A, Ringbom Å. 2003. Dating ancient mortar. American Scientist 91(2):130-7.

Heinemeier J, Jungner H, Lindroos A, Ringbom A, Von Konow T, Rud N. 1997. AMS ${ }^{14}$ C dating of lime mortar. Nuclear Instruments and Methods in Physics Research B 123(1-4):487-95.

Heinemeier J, Ringbom A, Lindroos A, Sveinbjornsdottir AE. 2010. Successful AMS ${ }^{14} \mathrm{C}$ dating of non-hydraulic lime mortars from the medieval churches of the Aland Islands, Finland. Radiocarbon 52(1):171-204.

Hodgins G, Lindroos A, Ringbom A, Heinemeier J, Brock F. 2011. ${ }^{14} \mathrm{C}$ dating of Roman mortarspreliminary tests using diluted hydrochloric acid injected in batches. Commentationes Humanarum Letterarum 128:209-13.

Idorn GM, Thaulow N. 1983. Examination of 136 years old Portland cement concrete. Cement and Concrete Research 13(5):739-43.

Jackson M, Marra F. 2006. Roman stone masonry: volcanic foundations of the ancient city. American Journal of Archaeology 110:403-36.

Kosednar-Legenstein B, Dietzel M, Leis A, Stingl K. 2008. Stable carbon and oxygen isotope investigation in historical lime mortar and plaster-results from field and experimental study. Applied Geochemistry 23(8): 2425-37.
Lanas J, Bernal JLP, Bello MA, Galindo JIA. 2004. Mechanical properties of natural hydraulic limebased mortars. Cement and Concrete Research 34(12):2191-201.

Lawrence P, Cyr M, Ringot E. 2003. Mineral admixtures in mortars: effect of inert materials on shortterm hydration. Cement and Concrete Research 33(12):1939-47.

Lindroos A. 2005. Carbonate phase in historical lime mortars and pozzolana concrete: implication for ${ }^{14} C$ dating. Department of Geology and Mineralogy, Abo Akademi University. PaintaloGillot.

Lindroos A, Heinemeier J, Ringbom À, Braskén M, Sveinbjörnsdóttir Á. 2007. Mortar dating using AMS ${ }^{14} \mathrm{C}$ and sequential dissolution: examples from Medieval, non-hydraulic lime mortars from the Åland Islands, SW Finland. Radiocarbon 49(1):47-67.

Lindroos A, Heinemeier J, Ringbom A, Brock F, Sonck-Koote P, Pehkonen M, Suksi J. 2011. Problems in radiocarbon dating of Roman pozzolana mortars. Building Roma Aeterna, Proceeding of the Conference March 2008. CommentationesHumanarumLetterarum 128: 214-230.

Lubritto C, Caroselli M, Lugli S, Marzaioli F, Nonni S, Marchetti Dori S, Terrasi F. 2015. AMS radiocarbon dating of mortar. The case study of the medieval UNESCO site of Modena. Nuclear Instrument and Methods in Physics Research B 361:614-9.

Marzaioli F. 2011. Characterization of a new protocol fro mortar dating: ${ }^{13} \mathrm{C}$ and ${ }^{14} \mathrm{C}$ evidences. Il Nuovo Cimento, Societa Italiana di Fisica 5:217-26.

Marzaioli F, Borriello G, Passariello I, Lubritto C, De Cesare N, D’Onofrio A, Terrasi F. 2008. Zinc reduction as an alternative method for AMS radiocarbon dating: process optimization at CIRCE. Radiocarbon 50(1):139-49.

Marzaioli F, Lubritto C, Nonni S, Passariello I, Capano M, Terrasi F. 2011. Mortar radiocarbon dating: preliminary accuracy evaluation of a novel methodology. Analytical Chemistry 83(6): 2038-45.

Marzaioli F, Nonni S, Passariello I, Capano M, Ricci P, Lubritto C, De Cesare N, Eramo G, Castillo JAQ, Terrasi F. 2013. Accelerator mass spectrometry ${ }^{14} \mathrm{C}$ dating of lime mortars: methodological aspects and field study applications at CIRCE (Italy). Nuclear Instruments and Methods in Physics Research B 294:246-51.

Marzaioli F, Lubritto C, Nonni S, Passariello I, Capano M, Ottaviano L, Terrasi F. 2014. Characterisation of a new protocol for mortar dating: ${ }^{14} \mathrm{C}$ evidences. Open Journal of Archaeometry 2:5264.

Massazza F. 1993. Pozzolanic cements. Cements and Concrete Composites 15(4):185-214.

Mathews JP. 2001. Radiocarbon dating of architectural mortar: a case study in the Maya region, Quintana Roo, Mexico. Journal of Field Archaeology 28(3-4):395-400. 
McCrea JMJ. 1950. Isotopic chemistry of carbonates and a paleo-temperature scale. Journal of Chemical Physics 18:849-57.

Michalska D, Pazdur A, Czernik J, Szczepaniak M, Zurakowska M. 2013. Cretaceous aggregate and reservoir effect in dating the binding materials. Geochronometria 40(1):33-41.

Michalska D, Czernik J. 2015. Carbonates in leaching reactions in context of ${ }^{14} \mathrm{C}$ dating. Nuclear Instruments and Methods in Physics Research B 361:431-9.

Miriello D, Barca D, Bloise A, Ciarallo A, Crisci GM, De Rose T, Gattuso C, Gazineo F, La Russa M. 2010. Characterisation of archaeological mortars from Pompeii (Campania, Italy) and identification of construction phases by compositional data analysis. Journal of Archaeological Sciences 37:2207-23.

Moropoulou A, Bakolas A, Bisbikou K. 2000. Investigation of the technology of historic mortars. Journal of Cultural Heritage 1(1):45-8.

Moropoulou A, Cakmak AS, Biscontin G, Bakolas A, Zendri E. 2002. Advanced Byzantine cement based composites resisting earthquake stresses: the crushed brick/lime mortars of Justinian's Hagia Sophia. Construction and Building Materials 16(8):543-52.

Moropoulou A, Bakolas A, Anagnostopoulou S. 2005. Composite materials in ancient structures. Cement \& Concrete Composites 27:295-300.

Morricone A, Macchia A, Campanella L, David M, De Togni S, Turci M, Maras A, Meucci C, Ronca S. 2013. Archaeometrical analysis for the characterization of mortars from Ostia Antica. Proceeding of Youth in Conservation of Cultural Heritage, YOCOCU 2012. Procedia Chemistry (8):231-8.

Nawrocka D, Michniewicz J. 2010. The radiocarbon dating of mortars from Wielka Waga, The Great Scales building in the Krakow market square. Proceeding of the 37th International Symposium on Archaeometry. Springer: 517-524.

Nawrocka DM, Michniewicz J, Pawlyta J, Pazdur A. 2005. Application of radiocarbon method for dating of lime mortars. Geochronometria 24:109-15.

Nawrocka D, Czernik J, Goslar T. 2009. ${ }^{14}$ C dating of carbonate mortars from Polish and Israeli sites. Radiocarbon 51(2):857-66.

Nonni S. 2014. An innovative method to select a suitable fraction for mortar ${ }^{14} \mathrm{C}$ dating: the Cryo2SoniC protocol [PhD dissertation]. Department of Earth Sciences, University of Rome Sapienza. Available from database Padis, Uniromal: http:// hdl.handle.net/10805/2402.

Nonni S, Marzaioli F, Secco M, Passariello I, Capano M, Lubritto C, Mignardi S, Tonghini C, Terrasi F. 2013. ${ }^{14} \mathrm{C}$ mortar dating: the case of the medieval Shayzar citadel, Syria. Radiocarbon 55(2-3):514-25.

Ortega LA, Cruz Zuluaga M, Alonso-Olazabal A, Inasausti M, Murelaga X, Ibanez A. 2012. Improved Sample Preparation Methodology on
Lime Mortar for Reliable ${ }^{14} \mathrm{C}$ Dating. Radiometric Dating. InTech. p 3-20.

Pachiaudi C, Marechal J, Van Strydonck M, Dupas M, Dauchot-Dehon M. 1986. Isotopic fractionation of carbon during carbon dioxide absorption by mortar. Radiocarbon 28(2):691-7.

Pesce GLA, Quarta G, Calcagnile L, D'Elia M, Cavaciocchi P, Lastrico C, Guastella R. 2009. Radiocarbon dating of lumps from aerial lime mortars and plasters: methodological issues and results from San Nicolò of Capodimonte Church (Camogli, Genoa, Italy). Radiocarbon 51(2):867-72.

Pesce GLA, Ball RJ, Quarta G, Calcagnile L. 2012. Identification, extraction, and preparation of reliable lime samples for ${ }^{14} \mathrm{C}$ dating of plasters and mortars with the "pure lime lumps" technique. Radiocarbon 54(3-4):933-42.

Reimer PJ, Bard E, Bayliss A, Beck JW, Blackwell PG, Bronk Ramsey C, Grootes PM, Guilderson TP, Haflidason H, Hajdas I, Hatte C, Heaton TJ, Hoffmann DL, Hogg AG, Hughen KA, Kaiser KF, Kromer B, Manning SW, Niu M, Reimer RW, Richards DA, Scott EM, Southon JR, Staff RA, Turney CSM, van der Plicht J. 2013. IntCal13 and Marine13 radiocarbon age calibration curves 0-50,000 years cal BP. Radiocarbon 55(4):1869-87.

Richardson IG. 1999. The nature of C-S-H in hardened cement. Cement and Concrete Research 29(8):1131-47.

Ringbom A, Hale J, Heinemeier J, Lindroos A, Brock F. 2006. Mortar dating in medieval and classical archaeology. Construction History Society Newsletter 73:11-8.

Ringbom A, Heinemeier J, Lindrooos A, Brock F. 2011. Mortar dating and Roman pozzolana results and interpretations. Commentationes Humanarum Letterarum 128:187-208.

Ringbom A, Lindroos A, Heinemeier J, Sonck-Koota P. 2014. 19 years of mortar dating: learning from experience. Radiocarbon 56(2):619-35.

Rittmann EA. 1933. Die geologische bedingte evolution und differentiation des SommaVesuvius magmas. Zeitschrift fur Vulkanologie 15:1-2.

Rozanski K, Stichler W, Gonfiantini R, Scott EM, Beukens RP, Kromer B, van der Plicht J. 1992. The IAEA ${ }^{14} \mathrm{C}$ intercomparison exercise 1990. Radiocarbon 34(3):506-19.

Salama AIA. 2000. Mechanical techniques: particle size separation. In: Wilson AD, editor. Encyclopedia of Separation Science. Oxford Academic Press. p 3277-89.

Sanchez-Moral S, Luque L, Canaveras JC, Soler V, Garcia-Guinea J, Aparicio A. 2005. Limepozzolana mortars in Roma catacombs: composition, structures and restoration. Cement and Concrete 35(8):1555-65.

Seinfield JH, Pandis SN. 2006. Atmospheric Chemistry and Physics: from Air Pollution to Climate Change. John Wiley and Sons. 
Staccioli RA. 2002. Acquedotti, fontane e terme di Roma antica. Newton \& Compton. 253 p.

Stefanidou M, Papayianni I. 2005. The role of aggregates on the structure and properties of lime mortars. Cement and Concrete Composites 27(9-10):914-9.

Stuiver M, Smith CS. 1965. Radiocarbon dating of ancient mortar and plaster. 6th International Conference on Radiocarbon and Tritium Dating. Pullman, WA: 338-43.

Stuiver M, Polach HA. 1977. Discussion: reporting of ${ }^{14}$ C data. Radiocarbon 19(3):355-63.

Terrasi F, De Cesare N, D'Onofrio A, Lubritto C, Marzaioli F, Passariello I, Rogalla D, Sabbarese C, Borriello G, Casa G, Palmieri A. 2008. High precision ${ }^{14} \mathrm{C}$ AMS at CIRCE. Nuclear Instruments and Methods in Physics Research B 266(10):2221-4.

Tomassetti G. 1926. La Campagna Romana Antica, Medioevale e Moderna. Volume 4. Loescher \& Co. p 80-4.
Valeri V. 2001. Brevi note sulle Terme a Porta Marina ad Ostia. Archeologia Classica 52:306-22.

Van Strydonck M, Dupas M, Dauchotdehon M, Pachiaudi C, Marechal J. 1986. The influence of contaminating (fossil) carbonate and the variations of $\delta^{13} \mathrm{C}$ in mortar dating. Radiocarbon 28(2A):702-10

Van Strydonck M, Van der Borg K, De Jong A, Keppens E. 1992. Radiocarbon dating of lime fractions and material from buildings. Radiocarbon 34(3):873-9.

Ventriglia U. 1971. La Geografia della Città di Roma. Rome: Amministrazione Provinciale di Roma.

Vitruvius. 1931. In: Granger VF, translator. De Architectura. Heinemann.

Ward-Perkins JB. 1979. Architettura Romana. Electa. $258 \mathrm{p}$.

Wilson R, Spengler JD. 1996. Particles in Our Air. Harvard University Press. 